

\title{
33679000602088
}

BNWL- 188

UC-25, Metals, Ceramics, and Materials

\section{A BRIGHT-FIELD, GRAIN STRUCTURE ETCH \\ FOR DELTA PHASE STABILIZED PLUTONIUM}

\author{
By \\ D. D. Hays \\ Metallurgy Development \\ Reactor and Materials \\ Technology Department
}

$$
\text { February, } 1966
$$




\section{A BRIGHT FIELD GRAIN STRUCTURE ETCH \\ FOR DELTA PHASE STABILIZED \\ PLUTONIUM}

\section{INTRODUCTION}

This paper describes the development of a bright-field, grain structure etch usable on delta phase, stabilized plutonium alloys regardless of their metallurgical condition.

Grain structure etchants in common usage for delta phase, stabilized plutonium alloys are based on the production of an adherent-surface, oxide layer to permit examination under polarized light. Attempts to use this method on cored delta phase stabilized alloys have not been successful, and only fair results have been obtained on homogenized alloys; therefore, a better etching technique for these alloys needed to be developed. SUMMARY

An oxide-free surface delineating grain boundaries was produced in delta phase, stabilized plutonium alloys having a variety of metallurgical treatments. Zirconium stabilized alloys were etched with solutions based on orthophosphoric, tetraphosphoric or citric acid. Delta phase plutonium stabilized with aluminum or gallium could only be etched with $200 \mathrm{ml}$ ethanol, $116 \mathrm{~g}$ citric acid and $10 \mathrm{~m} 1$ of a solution of either potassium or sodium nitrate in $100 \mathrm{ml}$ of water.

\section{EXPERIMENTAL PROCEDURE}

Equipment

The etching development was done with a Zeiss electro-polisher, which allows the metallographer to observe the metal surface at approximately $200 \mathrm{X}$ magnification during electro-polishing. This observation is highly desirable because the metallographer can watch the microstructure develop during etching and can stop etching when the best structure is obtained. Viewing the sample surface during etching is also advantageous in etchant evaluation or development since corrosion or pitting of the surface is easily seen. The current density versus voltage for any electrolyte can easily be determined. The visual observation of the behavior of the metal surface at different portions of this curve makes etchant evaluation an easier job.

A cross-sectional sketch of this equipment and its interior design is illustrated in Figure 1. (1) The unique feature of this unit is the combination of an electrolytic cell and an incident light microscope. The sample (1) is held by a spring loaded stainless steel plunger (2) (which also serves as the anode of the electrolytic cell) against a small orifice (3). The electrolyte, contained in a small dish (4), is pumped by a plastic coated pump (5) to the front end of the unit and flows across the sample surface back to the dish. A stainless steel cup with a small window in the end (6) protects the microscope objective and also serves as the cathode connection for the electrolytic cell. The light for microscopic observation during etching passes through air, glass, and the electrolyte.

(1) F. Raemmele and K. Veit. "A New Polishing Concept from East Germany, Metals Progress, vol. 81. no. 1. January,-1962: 


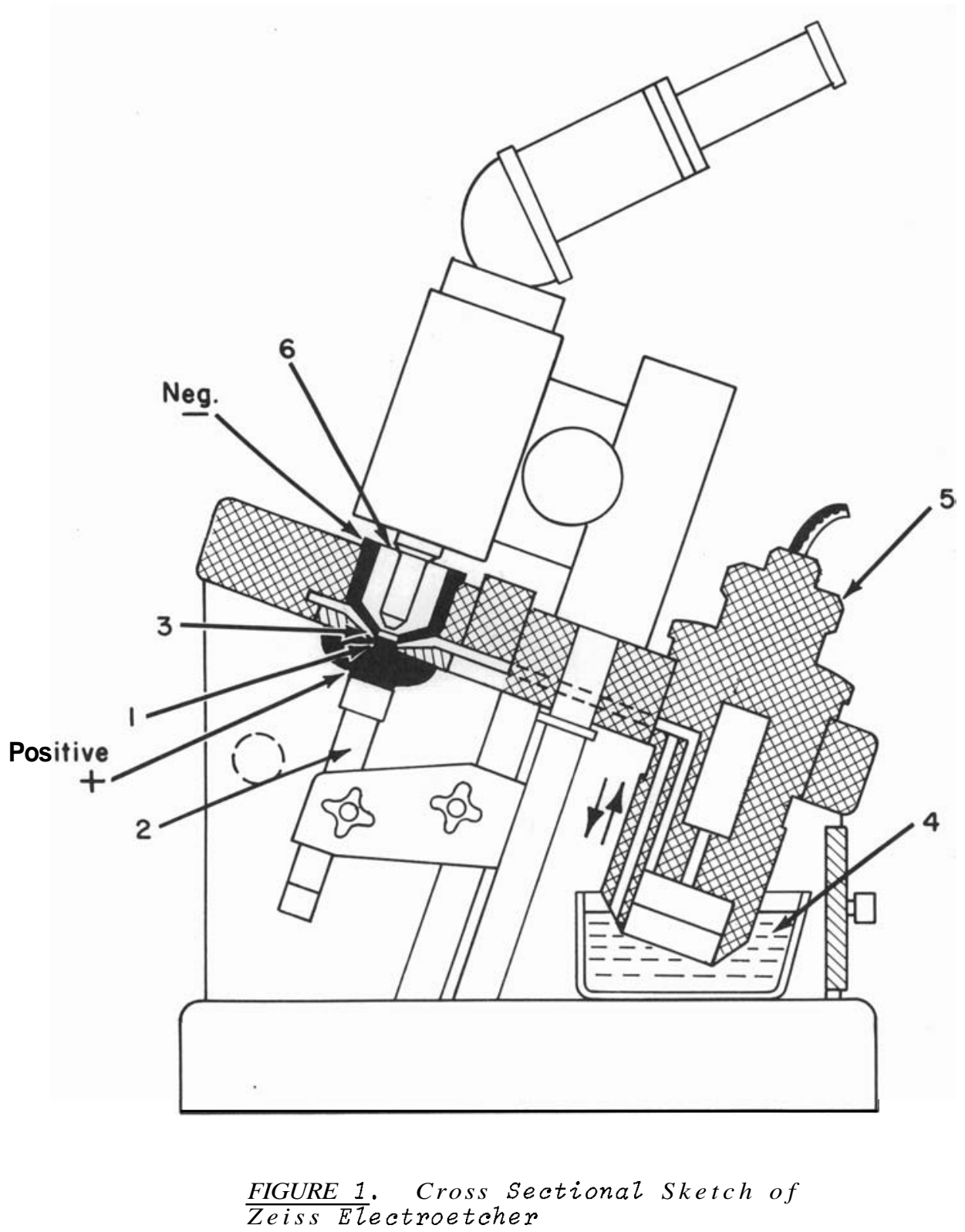

Most of the samples to be etched are mounted in a nonelectrical conducting, polyester resin; therefore, electrically conductive paint is used to make electrical contact between the stainless steel plunger (2, Figure 1) and the mounted sample. Figure 2 shows a painted, mounted sample in place and ready to etch.

The Zeiss etcher was placed in a small satellite glove box connected to the metallographic glove box with a plastic sleeve. Figure 3 shows the etcher in operation.

Sample Preparation

Specimens are mounted in polyester resin in $\mathbf{3 / 4}$ in. ID teflon molds. After removal of the mounted samples from the molds, they are faced flat on a small lathe in successive increments of $0.010,0.005,0.002,0.002,0.001$ and 0.001 in. to minimize surface 


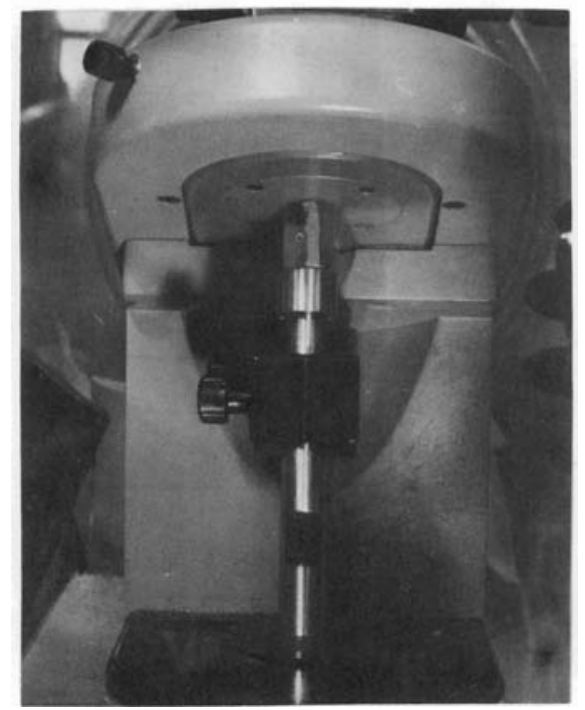

FIGURE 2. A Sample Ready for Etching
in the Zeiss Electropolisher. E-5373

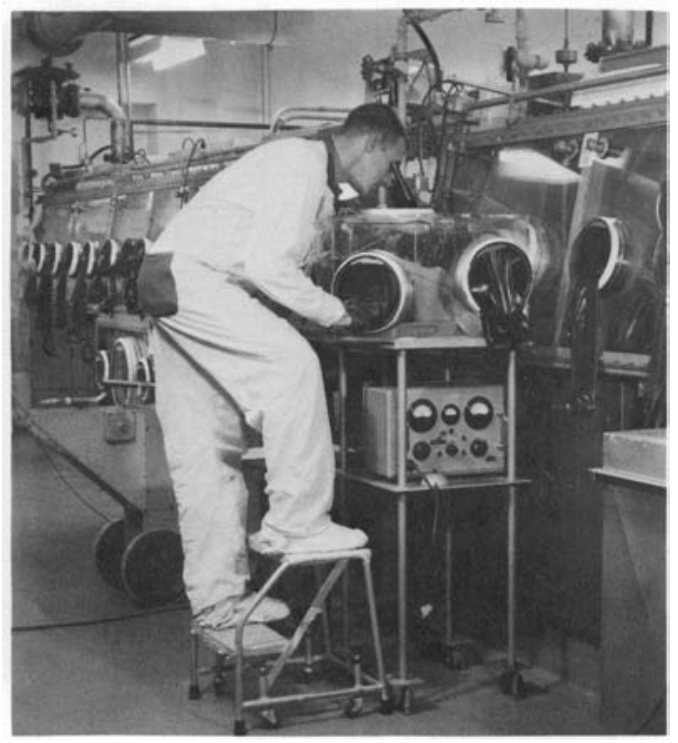

FIGURE 3. Glove Boxed Zeiss Electropolisher in Operation. E-5374

strain. The samples are then ground on 180,320 , and 600 mesh SiC grit cloths on 240 rpm lapping wheels, using carbon tetrachloride as a lubricant. Rough polishing was done, on a Syntron vibratory polisher, using a slurry of $6 \mu$ aluminum oxide in carbon tetrachloride on silk. The final polishing, also on a Syntron vibratory polisher, was on Microcloth, using a slurry of $0.3 \mu$ aluminum oxide in carbon tetrachloride. Prior to etching, the mounted sample is painted with electrically conducting paint.

RESULTS AND DISCUSSION

A large number of etchant compositions were investigated in this study. Components of the various etches are shown in Table I.

Delta phase, stabilized plutoniumzirconium alloys were quite easy to etch. A bright-field, grain structure was produced on $\mathrm{Pu}-10,15$ and $20 \mathrm{wt}$. \% Zr alloys in various metallurgical conditions, with etchants based on orthophosphoric acid, tetraphosphoric acid or citric acid. Figure 4 shows a homogenized $\mathrm{Pu}-15$ wt. $\mathrm{Zr}$ alloy etched in $30 \mathrm{ml}$ water, $150 \mathrm{ml}$ 2-ethoxyethanol, $20 \mathrm{ml}$ tetraphosphoric acid for 2 min at $10 \mathrm{~mA} / \mathrm{cm}^{2}$.

Figures 5 and 6 illustrate two different heat treatments of $\mathrm{Pu}-10$ wt. $\% \mathrm{Zr}$ alloys etched in $110 \mathrm{ml}$ ethanol, $50 \mathrm{ml}$ ethylene glycol and $20 \mathrm{ml}$ orthophosphoric acid for 1 min at 14 $\mathrm{mA} / \mathrm{cm}^{2}$.

The only etchant producing an oxide free surface that delineated grain boundaries in $\mathrm{Pu}-4$ at.\% Al or $\mathrm{Pu}-0.8$, 1.0 and 1.3 wt.\% Ga alloys was $200 \mathrm{ml}$ ethanol, $116 \mathrm{~g}$ citric acid and $10 \mathrm{ml}$ of a solution of $25 \mathrm{~g}$ of either $\mathrm{KNO}_{3}$ or $\mathrm{NaNO}_{3}$ in $100 \mathrm{ml}$ of water. When used at 5-10 V an excellent grain boundary etch is produced in 2 to 3 min regardless of the thermal treatment. Additions of an equivalent amount of $\mathrm{HNO}_{3}$ water solution did not yield results comparable to the $\mathrm{KNO}_{3}$ or $\mathrm{NaNO}_{3}$ water solution. Results obtained with calcium, nickel, copper or iron nitrates were also unsuitable. 


\section{TABLE I \\ COMPONENTS FOR ETCHANT EVALUATION FOR STABILIZED \\ DELTA PHASE PLUTONIUM ALLOYS}

$\underline{\text { Acids }}$

Nitric

Orthophosphoric

Tetraphosphoric

Sulfuric

Acetic

Chromic

Citric

Oxalic

\section{$\underline{\text { Solvents }}$}

Ethanol

Methanol

2 -ethoxyethanol

Hydrogen peroxide

Ethylene glycol

Water

\section{Other}

Halide salts Nitrate salts

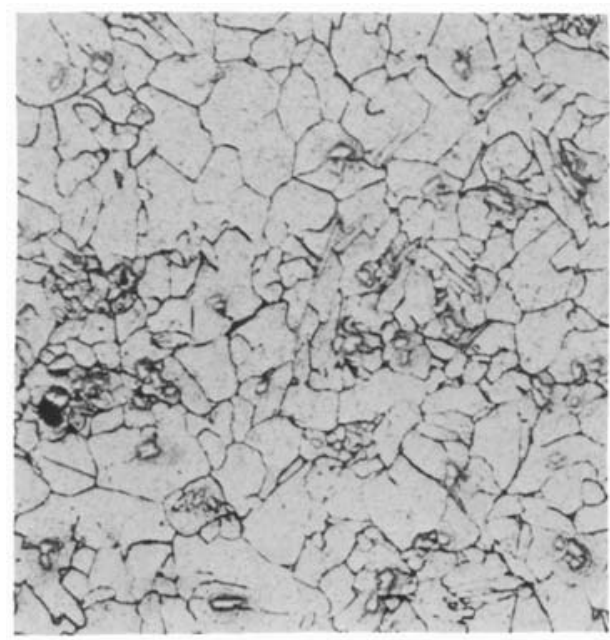

FIGURE 4. Homogenized Pu-15 wt\% Zr. Etched. R-5976 $500 X$.

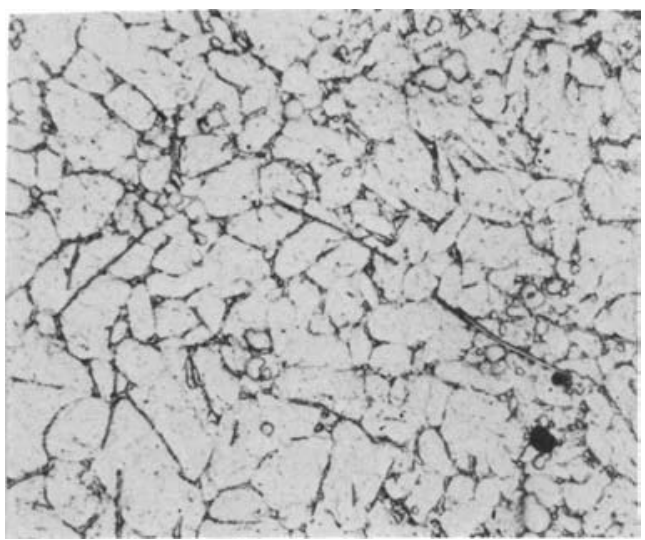

FIGURE 5. Pu-10 wt\% Zr AZZoy Heat $\overline{\text { Treated }} 8$ hrat $230{ }^{\circ} \mathrm{C}$. Etched. 500X. $R-6426$

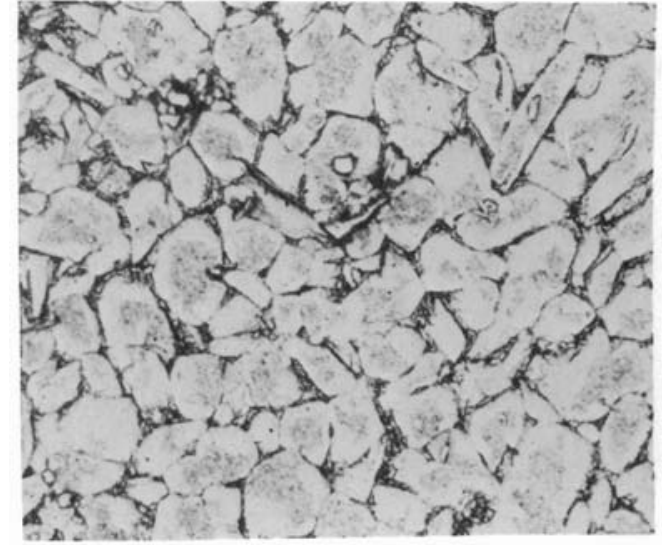

FIGURE 6. Pu-10 wt\% Zr A.Z2oy Aeat Treated $2 \mathrm{hr}$ at $500{ }^{\circ} \mathrm{C}$ and $26 \mathrm{hr}$ at $230{ }^{\circ} \mathrm{C}$. Etched. 500X. R-6414

Figure 7 illustrates the microstructure of as-cast Pu-4 at.\% Al alloy. Note that although the coring has caused a difference in etching rate, which produces surface relief, excellent grain structure is obtained. Figure 8 shows the same alloy after cold working and homogenization for $150 \mathrm{hr}$ at $450{ }^{\circ} \mathrm{C}$.

Figures 9, 10, and $\mathbf{1 1}$ are of homogenized $\mathrm{Pu}-0.8,1.0$ and 1.5 wt.\% Ga alloys etched with the citric acid, ethanol, nitrate solution at 5 to $10 \mathrm{~V}$ for 1 to 2 min. 
Figures 12,13 , and 14 are aspolished and etched structures of $\mathrm{Pu}-1$ wt. \% Ga samples with different cooling rates. The sample in Figure 12 has been cooled at $1{ }^{\circ} \mathrm{C} / \mathrm{min}$ from $775{ }^{\circ} \mathrm{C}$ to $640{ }^{\circ} \mathrm{C}$ (epsilon portion of equilibrium diagram) and quenched to room temperature. The sample in Figure 13 was cooled from $775{ }^{\circ} \mathrm{C}$ at $15^{\circ} \mathrm{C} / \mathrm{min}$ to $640{ }^{\circ} \mathrm{C}$ and quenched to room temperature. Large core clusters can be seen in the as-polished structure as a result of the $15^{\circ} \mathrm{C} / \mathrm{min}$ through the liquid plus epsilon region of the Pu-Ga equilibrium phase diagram. After etching, these large core clusters consist of similarly oriented fine

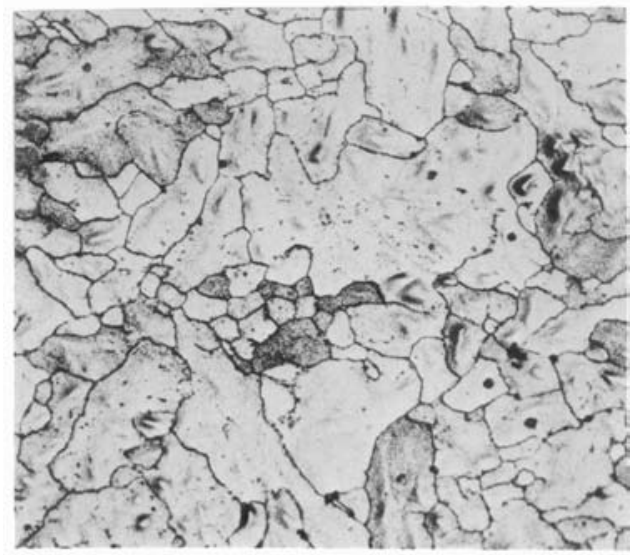

FIGURE 7. As-cast. Pu-4 at.\% AZ AZZoy. Etched. 150X. R-6093

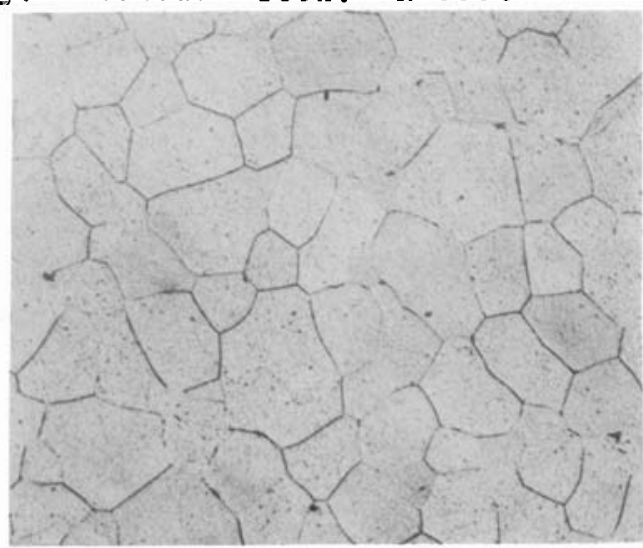

FIGURE 8. Cold Worked and Homogenized Pu-4 at.\% Al AZZoy. Etched. $250 X$. $R-6334$

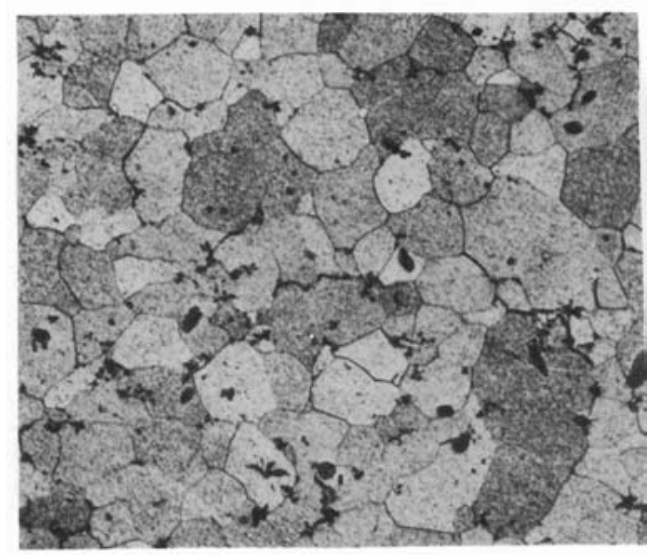

FIGURE 9. Pu-0.8 wt\% Ga AZZoy Homogenized 150 hr at $450{ }^{\circ} \mathrm{C}$. Etched. 250X. R-6345

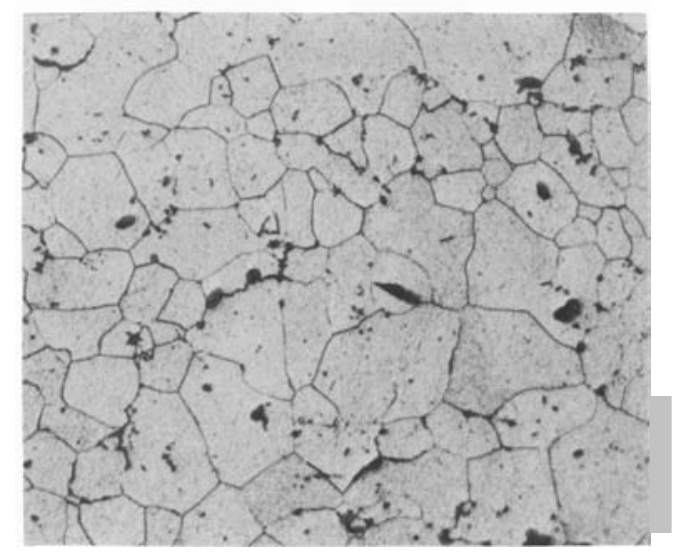

FIGURE 10. Pu-1.0 wt\% Ga AZZay Homogenized $150 h r$ at $450{ }^{\circ} \mathrm{C}$. Etched. 250X. $R-6348$

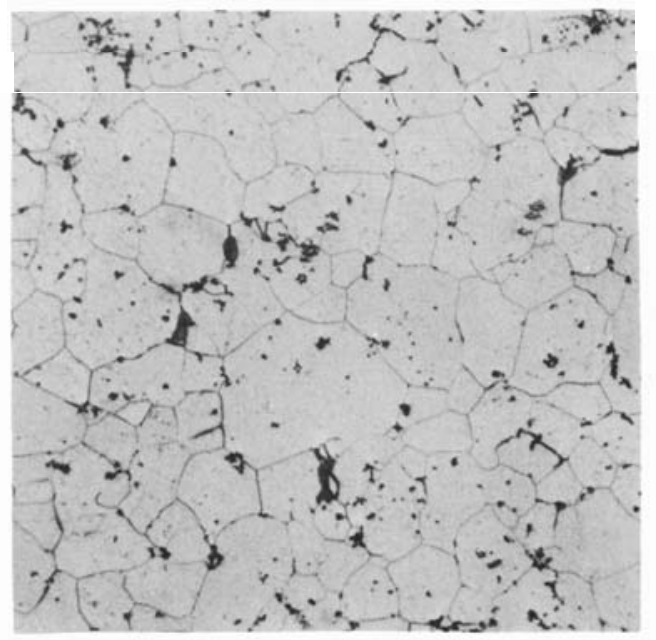

FIGURE 11. Pu-1.3 wt\% Ga AZZoy Homogenized 150 hrat $450{ }^{\circ} \mathrm{C}$. Etched. $250 X . \quad R-6350$ 


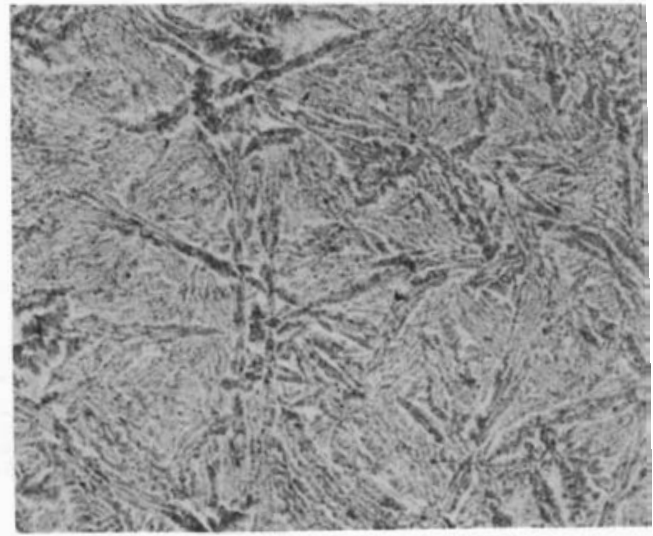

A. As-polished. 250X. R-6455

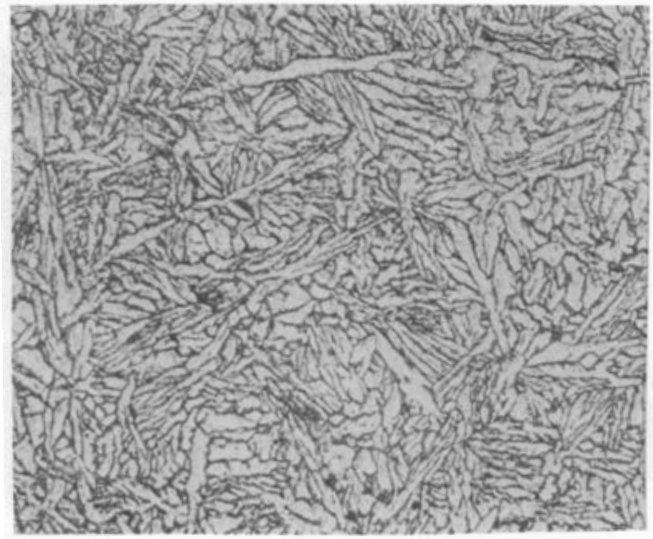

B. Etched. 250X. R-6456.

FIGURE 12. Pu-1 wt\% Ga AZZoy Cooled at $1{ }^{\circ} \mathrm{C} / \mathrm{m} i n$ from $775{ }^{\circ} \mathrm{C}$ to $640{ }^{\circ} \mathrm{C}$ and Quenched

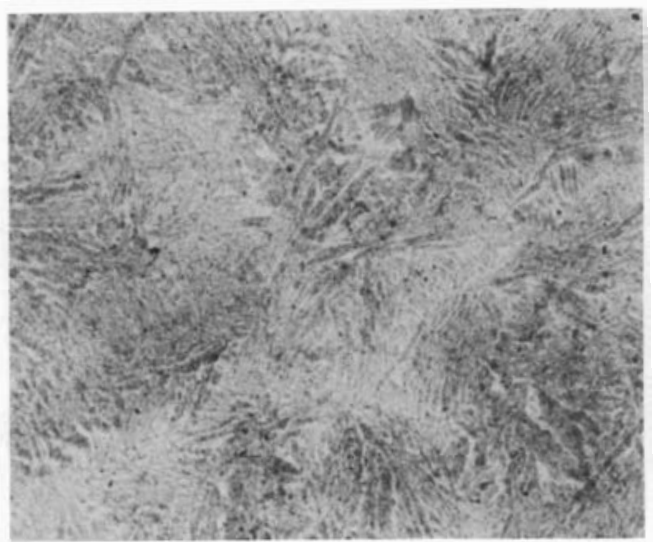

A. As-polished. 250X. R-6453.

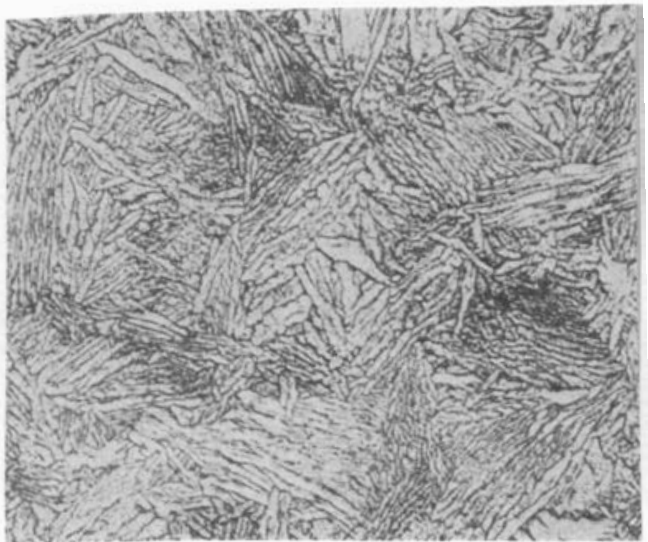

B. Etched. 250X. R-6457.

\section{FIGURE 13. Pu-1 wt\% Ga Alloy Cooled at $15{ }^{\circ} \mathrm{C} / \mathrm{min}$ from $775{ }^{\circ} \mathrm{C}$ to $640{ }^{\circ} \mathrm{C}$ and Quenched}

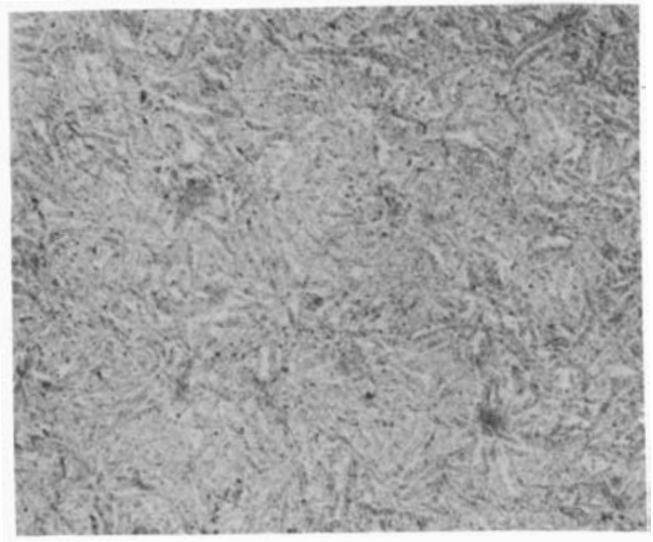

A. As-polished. 250X. R-6454.

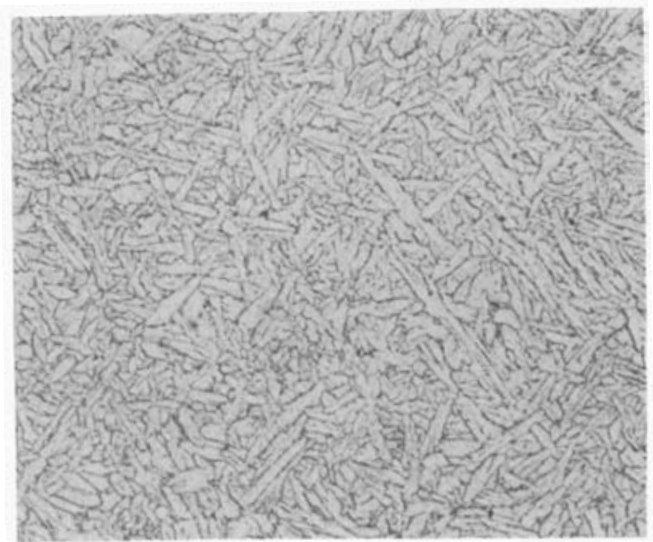

B. Etched. 250X, R-6458.

FIGURE 14. Pu-1 wt\% Ga Alloy Cooled at $15{ }^{\circ} \mathrm{C} / \mathrm{min}$ from $775{ }^{\circ} \mathrm{C}$ to $640{ }^{\circ} \mathrm{C}$ Held at $640{ }^{\circ} \mathrm{C}$ for $15 \mathrm{~min}$ and Quenched 
grains. The rest of the structure results from the quench from $640{ }^{\circ} \mathrm{C}$ and is similar to the grain structure in Figure 12. The sample in Figure 14 was cooled from $775{ }^{\circ} \mathrm{C}$ at $15{ }^{\circ} \mathrm{C} / \mathrm{min}$ to $640{ }^{\circ} \mathrm{C}$, held at $640{ }^{\circ} \mathrm{C}$ for $15 \mathrm{~min}$, and then quenched to room temperature. During the $15 \mathrm{~min}$ hold at $640{ }^{\circ} \mathrm{C}$, the large core clusters have disappeared because of homogenization. (2)

Figure 15 is the etched microstructure of a Pu-1 wt. $\%$ Ga alloy cast into a $625{ }^{\circ} \mathrm{C}$ mold, cooled at approximately 3 to $5{ }^{\circ} \mathrm{C} / \min$ to $425{ }^{\circ} \mathrm{C}$, held for about $1 \mathrm{hr}$ at $425{ }^{\circ} \mathrm{C}$, and slow cooled to room temperature. Sharp grain boundaries are evident even though the grains are cored.

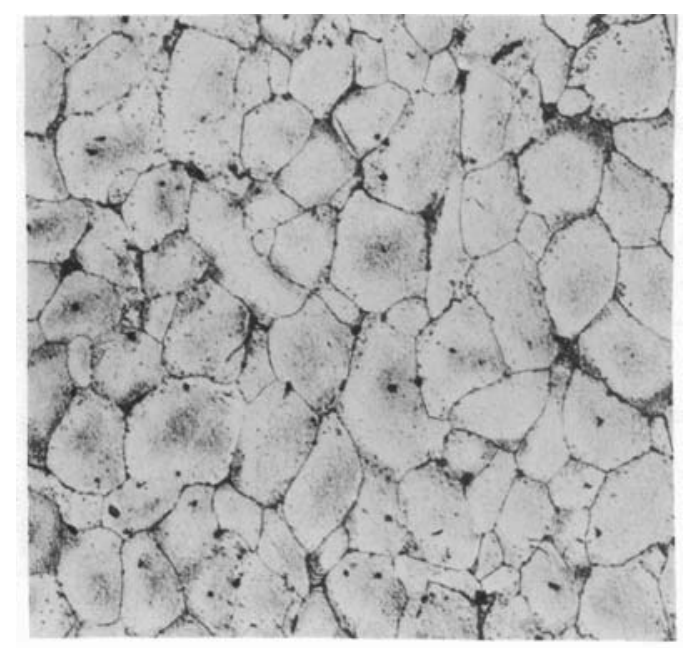

FIGURE 15. Pu-1 wt\% Ga AZZoy Cast into a 625 ${ }^{\circ} \mathrm{C}$ Mold, Cooled at Approx. 3 to $5{ }^{\circ} \mathrm{C} / \mathrm{min}$ to $425{ }^{\circ} \mathrm{C}$, Held at $425{ }^{\circ} \mathrm{C}$ for 1 hr and Furnace Cooled to Room Temperature. $250 \mathrm{X} . \quad R-6520$

\section{CONCLUSIONS}

Excellent bright-field, grain structure delineation on delta phase plutonium stabilized with zirconium

(2) H. R. Gardner. Physical and Mechanical Metallurgy Studies on Delta Stabilized PlutoniumGallium Alloys, BNWL-13. April, 1965. was obtained by using any of the following etchants:

(1) $30 \mathrm{ml}$ water, $150 \mathrm{ml} 2$-ethoxyethanol,

20 m l tetraphosphoric acid;

(2) $110 \mathrm{ml}$ ethanol,

50 ml ethylene glycol,

$20 \mathrm{ml}$ orthophosphoric acid;

(3) $200 \mathrm{ml}$ ethanol,

$116 \mathrm{~g}$ citric acid,

$10 \mathrm{ml}$ of a solution of $25 \mathrm{~g}$ potassium or sodium nitrate per $100 \mathrm{ml}$ of water.

Bright field, grain structure delineation on delta phase plutonium stabilized with aluminum or gallium was obtained only with etch number 3 .

\section{ACKNOWLEDGMENTS}

The author wishes to thank D. G. Rencken for his help in developing this technique. 


\section{ONSITE DISTRIBUTION}

Copy Number

Pacific Northwest Laboratory

\begin{tabular}{|c|c|}
\hline \multirow{2}{*}{\multicolumn{2}{|c|}{ F. W. Albaugh }} \\
\hline & \\
\hline 2 & A. L. Bement \\
\hline 3 & F. E. Bowman \\
\hline 4 & J. J. Cadwe11 \\
\hline 5 & R. E. Falkoski \\
\hline 6 & H. R. Gardner \\
\hline 7 & S. M. G i 11 \\
\hline 8 & G. P. Hanneman \\
\hline 9 & L. A. Hartcorn \\
\hline $10-11$ & D. D. Hays \\
\hline 12 & Y. B. Katayama \\
\hline 13 & R. R. King, J r. \\
\hline 14 & G. A. Last \\
\hline 15 & L. C. Lemon \\
\hline 16 & J. E. Minor \\
\hline 17 & E. D. McCl anahan \\
\hline 18 & R. D. Nelson \\
\hline 19 & T. C. Nelson \\
\hline 20 & J. G. Pace \\
\hline 21 & C. S. Powers \\
\hline 22 & R. W. Stewart \\
\hline 23 & J. M. Taylor \\
\hline 24 & 0. J. Wick \\
\hline $25-29$ & Technical Information File \\
\hline 30 & Technical Publications \\
\hline \multicolumn{2}{|c|}{ Richland Operations Office } \\
\hline 31 & R. K. Sharp \\
\hline 32 & $\begin{array}{l}\text { Technical Information } \\
\text { Library }\end{array}$ \\
\hline \multicolumn{2}{|c|}{ OFFSITE DISTRIBUTION (SPECIAL) } \\
\hline \multicolumn{2}{|c|}{$\begin{array}{c}\text { Number of } \\
\text { Copies } \\
\end{array}$} \\
\hline 3 & $\begin{array}{l}\text { Dow Chemical Company, } \\
\text { Rocky Flats } \\
\text { Attn: R. D. Forest } \\
\text { R. L. Greeson } \\
\text { R. R. McDonald }\end{array}$ \\
\hline 16 & $\begin{array}{l}\text { University of California, } \\
\text { Livermore } \\
\text { Attn: C. 1'. Brockett(1) } \\
\text { W. J. Ramsey (15) }\end{array}$ \\
\hline
\end{tabular}

